\title{
On the never-ending road to Brexit: perspectives for the European Union - introducing this special issue

\author{
DAGMAR SCHIEK*
}

Queen's University Belfast

\begin{abstract}
Introduction
A $\mathrm{t}$ the time of publication of this special issue, 17 months have passed since UK Prime Minister Theresa May notified the European Council of the UK's intention to withdraw from the EU. This decision was based on less than 52 per cent majority of votes cast for leaving the EU, in a non-binding referendum, which represented about 37 per cent of the votes of those entitled to participate. For reasons entirely particular to the UK voting system, this moved a Parliament with a majority for remaining in the EU before the referendum to consistently supporting the government in its aspiration to leave the EU. ${ }^{1}$

However, when it comes to how exactly the UK should leave the EU there is less agreement. The government has drawn stark lines in the sand, of course. One, 'Brexit' does not, actually, mean Brexit as a shorthand for 'British exit from the EU'. Instead, the UK government plans to withdraw those parts of the UK whose population has endorsed remaining in the EU out of the EU as well - this includes Northern Ireland, rendering 'Brexit' a misnomer. Second, withdrawal from the EU will also mean withdrawal from the Internal Market - or at least the part where people gain rights to move and be treated equally in the UK - as well as the liberation from the jurisdiction of the Court of Justice of the European Union (CJEU). While this so-called 'hard Brexit' will harm the UK citizens economically, especially in the North of England, Scotland,
\end{abstract}

* The special issue resulted from the conference 'Brexit - 15 Months On' in September 2017 at Queen's University Belfast. This conference was funded by the project Tensions at the Fringes of the European Union - Regaining the Union's Purpose (TREUP), through Jean Monnet Centre of Excellence by the European Commission (Project Number 564869-EPP-1-2015-1-UK-EPPJMO-CoE). For some more immediate impressions of the conference, consult <https://blogs.qub.ac.uk/tensionatthefringes/2018/02/01/academic-conference-brexit-15-months-onsocio-legal-perspectives-for-the-eu-and-europe $>$.

1 For example, the government had no difficulty in securing a majority for the European Union (Notification of Withdrawal) Act, (2017) <www.legislation.gov.uk/ukpga/2017/9/pdfs/ukpga_20170009_en.pdf> only days after the UK Supreme Court found that Parliament, not government, must take this decision (R (Miller) $v$ Secretary of State for Exiting the European Union [2017] UKSC 5), nor failed to win parliamentary approval for the EU Withdrawal Act, which ends the viability of EU law in the UK as supranational law along with the authority of the CJEU and subjects most EU law to withdrawal by government regulation, reserving a parliamentary decision for only a few elements. 
Wales and Northern Ireland, ${ }^{2}$ this is unlikely to stop Brexit. For many, leaving the EU has become an emotional necessity, ${ }^{3}$ partly related to a perceived English or British identity imagined as alien to 'Europe' or resulting from peculiar imaginations of sovereignty. ${ }^{4}$

\section{The overall rationale of this issue}

There is, of course, a good chance that the UK, after experiencing the reality outside the EU, returns to the fold in the future. However, this will depend on whether the EU emerges stronger from this withdrawal, which is closely connected to its recurrent crises over the last decade. Next to the UK's idiosyncratic reasons to withdraw from the EU, ${ }^{5}$ those voting in favour of withdrawal also voiced more general concerns. Research frequently highlights a general discontent with underfunding of municipal services, deterioration of the economic situation and high unemployment or insecure employment conditions in certain regions, as well as anxiety around migration, estrangement from the EU institutions, and a perception that EU integration is an elite project, responsible for many ills of everyday life. ${ }^{6}$

Some of these sentiments are partially owed to the unique situation in the UK, which does not as a rule allocate tax income to regions in relation to tax revenue or necessary expenditure for public services. ${ }^{7}$ If coupled with longstanding austerity politics, this may result in more negative impact on public services than in other Member States. Some of the sentiments are not, however, unique to the UK, even though they do not prompt citizens in other EU Member States to reject continued EU membership for their country. For example, anxieties around arrival of EU citizens from abroad are part of a growing unease with migration in a number of EU Member States, resulting in a surge of support for right-wing populist parties in many. Some Member States' governments, notably Poland and Hungary, have already started to dismantle guarantees conventionally associated with liberal justice. ${ }^{8}$

Further, the EU's reactions to the global economic crisis, which mainly resulted in demanding that Member States reduce spending, preferably for social policy, and reform their employment laws, have resulted in an increase of socio-economic hardship in many Member States. Whether this hardship is rightly or wrongly blamed on the EU, its increase

2 See the detailed references in John Doyle and Eileen Connoly, 'Brexit and the Northern Ireland Question', in Federico Fabbrini (ed), The Law and Politics of Brexit (Oxford University Press 2017).

3 See Annette Bongardt and Francisco Torres, 'A Qualitative Change in the Process of European Integration', in Nazaré da Costa Cabral, José Renato Gonçalves and Nuno Cunha Rodrigues (eds), After Brexit: Consequences for the European Union (Palgrave Macmillan 2017) 102-27, 105-8, who relentlessly expose how the British electorate (minus the Scottish, and of course the Northern Irish) drifted towards supporting an ever harder Brexit between the referendum and the 2017 election.

4 Marlene Wind, 'Brexit and Euroscepticism. Will "Leaving Europe” be Emulated Elsewhere?' in Fabbrini (n 2) 219-46, 229-33.

5 See, for example, Anand Menon and John-Paul Salter, 'Brexit, Initial Reflections' (2016) 92(6) International Affairs 1297-318; Wind (n 4); Joseph H H Weiler, 'Brexit: No Happy Endings' (2015) 26 European Journal of International Law $1-7$.

6 For an early post-referendum overview, see Sara Hobolt, 'The Brexit Vote: A Divided Nation, a Divided Continent' (2016) 23 Journal of European Public Policy 1259-77; with hindsight, see John Curtice, 'Why Leave Won the UK's EU Referendum' (2017) 55 Journal of Common Market Studies 19-37.

7 For a comparison of redistribution through taxes in the EU, see Anna Iara, Wealth Distribution and Taxation in EU Member States (European Commission 2015); for an assessment of whether free movement of persons actually results in strains on public services (and exposing that such strains are notoriously overestimated in the public), see Klára Fóti, Social Dimension of Intra-EU Mobility: Impact on Public Services (Eurofund 2015).

8 Laurent Pech and Kim Scheppele, 'Illiberalism Within: Rule of Law Backsliding in the EU' (2017) 19 Cambridge Yearbook of European Legal Studies 3-47. 
constitutes a challenge to the EU's raison d'etre: the creation of the Internal Market (alias Common Market between 1957 and 1992) was never an aim in itself. Instead, the alldominant economic integration served the purpose of improving the living and working conditions throughout Europe. If significant parts of the EU citizenry perceive EU law and politics as failing in this endeavour, the Union itself suffers from a serious crisis of identity. ${ }^{9}$

All this indicates that Brexit can be viewed as a symptom for a substantive crisis of the EU. This view contrasts with the presentation of the EU's perils as three successive crises: ${ }^{10}$ the first of those was the global economic crisis emerging from volatile governance of the financial sectors in the USA (epitomised by the Lehmann Brothers bank crash in 2007), as well as some EU Member States, including the UK and Ireland. The second one was triggered by the surge in persons seeking refuge in Europe as a consequence of the 'Arab Spring' and the subsequent war in Syria from 2015, which again resulted from US and UK interventions in the region. Brexit is partially portrayed as an independent third crisis of potential escalating disintegration. The global financial crisis had repercussions in the EU of necessity, which exposed - depending on one's political standpoint - the weaknesses of the Eurozone based on the diversity of its constituent economies (lack of 'optimal currency area') or based on the incompleteness of economic and political integration achieved by the Maastricht Treaty due to hesitancy, among others, of the UK. ${ }^{11}$ The surge of refugees culminating in 2015 has exposed the difficulty of the EU to command Member States' solidarity within the framework of EU law. ${ }^{12}$ Instead of portraying Brexit as a crisis in its own right, ${ }^{13}$ it can also be viewed as but one expression of Euroscepticism caused cumulatively by the Eurozone crisis and the surge in refugees. ${ }^{14}$ While all these debates on individual crises have merit, we suggest that the

9 See on this Dagmar Schiek, 'Towards more Resilience for a Social EU: The Constitutionally Conditioned Internal Market' (2017) 13 European Constitutional Law Review 611-40.

10 Often referred to as 'triple crisis', e.g. James Caporaso, 'Europe's Triple Crisis and the Uneven Role of Institutions: The Euro, Refugees and Brexit' (2018) 56 Journal of Common Market Studies 1345-61.

11 See on this from socio-legal and interdisciplinary perspectives, Dagmar Schiek (ed), The EU Economic and Social Model in the Global Crisis: Interdisciplinary Perspectives (Ashgate 2013); Kaarlo Tuori and Klaus Tuori, The Eurozone Crisis: A Constitutional Analysis (Cambridge University Press 2014); from the perspective of political economy, see Peter Hall, 'Varieties of Capitalism in Light of the Euro Crisis' (2018) 25 Journal of European Public Policy 7-30; from the perspective of political science integration theory, Arne Niemann and Ioannou Demosthenes, 'European Economic Integration in Times of Crisis: A Case of Neo-Functionalism?' (2015) 22 Journal of European Public Policy 1-23. There are a number of recent expositions of macro-economic critique of the Eurozone law and practice, for example, Alison Johnston and Aidan Regan, 'Introduction: Is the European Union Capable of Integrating Diverse Models of Capitalism?’ (2018) 23 New Political Economy 145-59 and further articles in this special issue (guest eds Alison Johnston and Aidan Regan).

12 See from legal perspectives recently Christina Molinari, 'The EU and its Perilous Journey through the Migration Crisis: Informalisation of the EU Return Policy and Rule of Law Concerns' (SSRN 2018) <http://dx.doi.org/10.2139/ssrn.3171983>; from international human rights perspectives see Rachael McNeilly, 'Common European Asylum System: Contradictions and Crises' (2017) 4 Carleton Review of International Affairs 54-65; from sociological perspectives, see Nick Dines, Nicola Montagna and Elena Vacchelli (guest eds), 'Special Issue: Migration and Crisis in Europe' (2018) 52 Sociology 439-625; from the perspective of political science on both those crises, Tanja Börzel and Thomas Risse, 'From the Euro to the Schengen Crises: European Integration Theories, Politicization, and Identity Politics' (2018) 25 Journal of European Public Policy 83-108 and Philippe Schmitter and Zoe Lefkofridi, 'Using Neo-functionalism to Understand the Disintegration of Europe' in Hideko Magara (ed), Policy Change under New Democratic Capitalism (Routledge 2016) 171-200.

13 Ben Rosamond, 'Brexit and the Problem of European Disintegration' (2016) 12 Journal of Contemporary European Research 865-71.

14 Paul Taggart and Aleks Szczerbiak, Putting Brexit into Perspective: The Effect of the Eurozone and Migration Crises and Brexit on Euroscepticism in European States' (2018) 25 Journal of European Public Policy 1194-214. 
withdrawal of a Member State - even a notoriously reluctant one - illustrates that the individual crises of the EU add up to more than their sum, and suggest a deeper crisis of the EU, ${ }^{15}$ relating to its substantive constitutional aims. If that is the case, the EU not only needs to administer the first ever withdrawal of a Member State in a measured manner, not impacting more than necessary ${ }^{16}$ on relations with its stroppy Northwesterly neighbour poised to enhance perceived competitiveness through a deregulation campaign. ${ }^{17}$ There is also a necessity of reacting more fundamentally, and to refocus the EU on facing the future challenges of ecological and socio-economic sustainability while also re-engaging with its citizenry. Since the EU remains a project based on integration through law, ${ }^{18}$ the medium and long-term plans for responding to this situation will have to be grounded in its legal order, without neglecting the societal and political embeddedness of law. This special issue tackles this challenge with a focus on the substantive law of the EU, asking whether and how the EU should react to Brexit. It does so based on the idea that it is from the fringes of the EU that the need for change can best be observed. Accordingly, the issue assembles authors from Ireland (North and South), Finland, Poland and the UK (although with origins in Germany and Greece). Alongside debates on the future of EU citizenship, and environmental and social policy, the articles also discuss aspects of the rule of law crisis in Poland and perspectives of the EU's break-up for the island of Ireland. This selection is far from eclectic, as it addresses core aspects of the future of the EU as well as the challenges emanating from its Eastern and Western fringes.

\section{The never-ending flood of Brexit literature - socio-legal scholars}

Brexit has been a godsend for academia in the UK and beyond, as it created the opportunity for intensive research and publication activities. As a result, much ground has been covered already. Nevertheless, we humbly submit that we add to the existing sociolegal literature.

Initially, socio-legal reflections were justifiably focused on the consequences that Brexit will have for the UK, summarising the consequences of severing the bonds resulting from more than 40 years of legal integration. Considering whether the slogan 'Britain Alone' could become viable in the twenty-first century, ${ }^{19}$ the crème of British and Irish constitutional and public lawyers delivered the verdict that it would become very complicated, to say the least, and pose severe constitutional problems. At the same time the collection reflects on potential causes of Brexit, identifying the 'often haughtily detached decisions' 20 of the CJEU and the 'Death of Social Europe'21 as particular problems. This book does address the substantive law of the EU, but is mainly focused on the reflections within the UK prior to and beyond its withdrawal. Similarly, the 2016

15 This is also indicated by Ben Rosamond, 'Brexit and the Problem of European Disintegration' (2016) 12 Journal of Contemporary European Research 865-71; Schmitter and Lefkofridi (n 12).

16 As demanded by those supporting the liberal project of free trade, e.g. Jo Weiler, 'The Case for a Kinder, Gentler Brexit' (2107) 15 International Journal of Constitutional Law 1-8, 1-4.

17 Thomas Sampson, 'Brexit: The Economics of International Disintegration' (2017) 31 Journal of Economic Perspectives 163-83.

18 See the contributions in Daniel Augenstein, Integration through Law' Revisited: The Making of the European Polity (Ashgate 2012). For a critical assessment, see further Kaarlo Tuori, European Constitutionalism (Cambridge University Press 2015).

19 Patrick Birkinshaw and Andrea Biondi (eds), Britain Alone! The Implications and Consequences of United Kingdom Exit from the EU (Kluwer 2016).

20 Maria Kendrick, 'Judicial Protection and the UK's Opt Outs: Is Britain Alone in the CJEU?' in ibid \$9.01

21 The title of Keith Ewing's chapter in ibid. 
collection of short sections on Brexit by the European Law Review ${ }^{22}$ mainly focuses on consequences for the UK internal order, while identifying that the EU will need to engage in some fundamental reflection. ${ }^{23}$ Also, the consequences of Brexit on Economic and Monetary Union, alongside the role of austerity policies triggered by the EU's handling of the Eurozone crisis are reflected upon. ${ }^{24}$ A 2017 edited collection is explicitly dedicated to identifying legal and policy challenges in the UK after Brexit, offering a wideranging presentation and analysis of relevant areas. ${ }^{25}$ It should be added that all three publications also expose specific considerations for the UK's devolved regions: Northern Ireland, Scotland and Wales. ${ }^{26}$ The elevated position of EU citizenship rights, both in the perception by the EU and UK courts before any referendum was ever announced, and in the EU negotiation strategy, have been brilliantly analysed by Elspeth Guild, pursuing the hypothesis that a rights-based conceptualisation of citizenship must seem as a monstrosity to those used to the status-based concept of British nationality. Again, this book is firmly based on an UK-centred perspective. ${ }^{27}$ A critical internal perspective is also taken up in monographic length, but through a series of short essays in Brexit Time, ${ }^{28}$ attempting to explain to the legally informed reader 'what the hell is happening next'. ${ }^{29}$ Armstrong expands his approach later towards predicting in how far the UK will pursue the contrasting policies of regulatory alignment with or diversification from the EU. ${ }^{30}$

With the Brexit process moving on, socio-legal analysis proceeds as well, starting to go beyond the focus on the UK itself. Da Costa Cabral et als' collection of contributions by legal, political science and economic scholars ${ }^{31}$ explores the consequences of Brexit for the EU, not the UK. Bongardt and Torres urge the reader to accept Brexit as a reality, and forgo indulgence in phantasies that it may not happen. ${ }^{32}$ The main ambition of this volume is to predict the pragmatic legal consequences, such as regarding Brexit as a force majeure in relation to contractual obligations and to pragmatically develop different scenarios that could play out, such as developing models for social security coordination with the UK in the future. ${ }^{33}$ There are also some normative elements, such as demanding a serious discussion of which society the EU integration process should promote.

22 See the introduction by Jukka Snell, 'Editorial - Brexit: The Age of Uncertainty' (2016) 41 European Law Review 445-6.

23 Anthony Arnull, 'Broken Bats' (2016) 41 European Law Review 473-4.

24 Alicia Hinarejos, 'Brexit and the Euro Area' (2016) 41 European Law Review 478-80.

25 Michael Dougan (ed), The UK after Brexit. Legal and Policy Challenges (Intersentia 2017).

26 See the chapters by Gordon Anthony on Northern Ireland, Stephen Tierney and Katie Boyle on Scotland, and Mike Varney on Wales in Birkinshaw and Biondi (n 19). See also David Edwards and Niamh Nic Shuibhne, “'While Europe's Eye Is Fix'd on Mighty Things": Implications of the Brexit Vote for Scotland' (2016) 41 European Law Review 481-3, on Scotland, alongside Dougan's chapter on the Irish border and Hunt's chapter on devolution in Dougan (n 25).

27 Elspeth Guild, Brexit and its Consequences for UK and EU Citizenship: Or Monstrous Citizenship (Brill \& Nijhoff 2016).

28 Kenneth Armstrong, Brexit Time. Leaving the EU - Why, How and When? (Cambridge University Press 2017).

29 'Brexit - What the Hell Is Happening Now?' is the title of a journalistic exposure of the Brexit phenomenon aimed at a lay audience which has already seen its second edition: Ian Dunt, Brexit: What the Hell Happens Now? (2nd edn, Canbury Press 2018).

30 Kenneth Armstrong, 'Regulatory Alignment and Divergence after Brexit' (2018) 25 Journal of European Public Policy 1099-117.

31 Da Costa Cabral et al (n 3).

32 Bongardt and Torres (n 3).

33 Yves Jorens and Grega Strban, New Forms of Social Security for Persons Moving between the EU and the UK?' in da Costa Cabral et al (n 3) 268-313. 
Similarly, a 2018 University College London publication ${ }^{34}$ strives to rethink the future of Europe in shorter contributions by legal and political science scholars. Eight chapters address the consequences of Brexit for the UK and some other Member States and dependencies; four confront the future of the EU institutions; and six address EU constitutional questions, including how EU citizens will fare in the UK and vice versa, and the future of EU democracy. Further chapters attempt to predict the impact of Brexit on the euro area, and the EU's governmentality at large, while three more cover the EU's external policies. The three concluding chapters address the idea of Europe, and thus go to the ideational future of the EU.

Federico Fabbrini' s 2018 edited collection ${ }^{35}$ constitutes a combination of fact-finding chapters and those pursuing a classical liberal vision of the future EU. Based on intergovernmental liberalism, Kalypso Nicolaïdis ${ }^{36}$ sets the tone in theorising Brexit as yet another (legitimate) move of the UK to defend its control in a narrow conservative sense, a move which ultimately safeguards equilibrium. Catherine Barnard ${ }^{37}$ carries this over into the realm of the Internal Market, scolding the EU for refusing to grant the UK a permanent exception from applying free movement of workers while still being part of the Internal Market. Uwe Puetter ${ }^{38}$ proposes that the EU reconsiders the institutional balance, ensuring that the political weights are readjusted in order to achieve the 'control and equilibrium' proposed by Nicolaïdis. Member States, writes Puetter, 'cannot escape a paradoxical attitude towards integration, namely that they seek closer integration without supranational empowerment', ${ }^{39}$ rendering Franco-German leadership as demonstrated during the Euro crisis ${ }^{40}$ as problematic in the future in the absence of a British counterweight. Fabbrini ${ }^{41}$ adds in his own chapter that the EU should take Brexit as an opportunity to 'fix . . . problems', 42 and proposes institutional reforms to enhance the democratic legitimacy of the Eurozone alongside the creation of a Eurozone budget. ${ }^{43}$

\section{The contribution of this issue}

While at first sight it seems a daunting enterprise to endeavour adding anything to this rich literature, on closer inspection, some gaps emerge. As we have seen, the Brexit debate is frequently focused on the UK and the future special relationship between this state and the EU. Even the two collections which, as per their titles, aspire to develop perspectives for the EU, ${ }^{44}$ contain a substantive amount of debate focusing on how the UK can cope in the end with leaving the EU. While this certainly is very relevant, Bongardt and Torres refreshingly state a simple truth: 'Brexit is a priority for the UK. For the EU, it is a major

34 Benjamin Martill and Uta Staiger (eds), Brexit and Beyond. Retbinking the Futures of Europe (University College London 2018).

35 Fabbrini (n 2).

36 Kalypso Nicolaïdis, 'The Political Mantra: Brexit, Control and the Transformation of the European Order' in Fabbrini (n 2) 25-48.

37 Catherine Barnard, 'Brexit and the EU Internal Market' in Fabbrini (n 2) 201-18.

38 Uwe Puetter, 'Brexit and EU Institutional Balance: How Member States and Institutions Adapt Decisionmaking' in Fabbrini (n 2) 247-66.

39 Ibid 252.

40 Ibid 254.

41 Federico Fabbrini, 'Brexit and EU Treaty Reform: A Window of Opportunity for Constitutional Change?' in Fabbrini (n 2) 267.

42 Ibid 268.

43 The views on Brexit and Economic and Monetary Union have also been published in Federico Fabbrini, 'Brexit and the Reform of Economic and Monetary Union' in da Costa Cabral et al (n 3) 128-47.

44 Da Costa Cabral et al (n 3); Martill and Staiger (n 34). 
and costly distraction from important common challenges. 45 This truth must not, however, distract from the fact that the UK's withdrawal must be used as an chance to improve. Most importantly, the Union should use the opportunity to address popular discontent with its integration project on the one hand, and on the other hand tackle the thorny problem of coordinating policies which cannot stop at geographical borders through constructive engagement with the UK as a non-integrated close neighbour.

Both these necessities require engagement with the EU's substantive policies, rather than merely addressing institutional and governance issues. Because the EU continues to be a community of law, those socio-economic and political challenges should be addressed in socio-legal categories rather than exclusively as policy issues. The mission of this special issue is thus highly relevant, and not yet completed in other publications. In line with the main discontent with the EU, and the major problems which defy governance within the convenient constraints of secured borders, three partly interrelated themes emerge. EU citizenship is the first of these, followed by social and labour law and policy, and by realising environmental protection. Over all three of these themes, tensions between EU-wide rights guarantees and legal frames of integration on the one hand and regional policies and national closure movements on the other emerge. These tensions are epitomised by the EU's rule of law crisis and the challenges of maintaining hybrid territories and identities on the island of Ireland after Brexit.

Three articles engage with EU citizenship: as no other institutions, its introduction evoked the question of whether the peoples of Europe - the category referred to in Article 2(1) TEU - identify with the Union, and whether any such identification is justified by the granting of stable, consistent and reliable rights.

Stephen Coutts asks which possible avenues for the future direction of Union citizenship remain open after the UK's withdrawal, inter alia, on the grounds that 'citizens of nowhere' (Theresa May) were no longer countenanced. Instead of focusing on the individual fates of the many citizens who relied on citizenship rights and moved to the $\mathrm{UK}$, the article asks the question whether Union citizenship as an additional category to national citizenship is viable or rather contradicts 'certain forms of national social life'. It contrasts communitarian with cosmopolitan citizenship concepts, finding that this outworn dichotomy does little to resolve the dilemmas of a multidimensional concept such as Union citizenship. He finds the dichotomy to be useful in so far as it illuminates the danger of Union citizenship being of use only for the privileged few. Counterintuitively, he concludes that more rather than less citizenship will be needed to overcome its social hollowness and inherent threat to national citizenship as an institution.

Massimo Fichera uses citizenship and free movement rights of economically active citizens as a case study for his hypothesis that the EU is fundamentally a security project. In his conceptual definition of security, the concept embraces the existential identity of a polity. Guaranteeing the rule of law, democracy and human rights thus become pure instruments to safeguarding semantic, spatial, temporal and epistemic dimensions of security. Applying these categories to the specific problems of Union citizenship, Fichera concludes that the EU as a security project requires differentiated integration. Extending the options available under the concentric circles paradigm would in his view prevent further disintegration as epitomised by Brexit. However, the challenge remains as to how to ensure that differentiation does 'not come at the expense of the economic and social constitution', and in particular not at the expense of social rights.

45 Bongardt and Torres (n 3) 121. 
Konstanze von Papp takes up the challenges of also guaranteeing social citizenship rights for those citizens who are frequently accused of 'benefit tourism', a concept whose empirical validity she rejects. Nevertheless, she recognises that Member States may find difficulty in integrating EU citizens who are 'economically inactive' when they enter their territory. She frames the question under which circumstances EU citizens from other Member States must be granted equal treatment rights in relation to benefits as one of federalism. This leads her to an extensive comparison of case law (and legislation) in the USA and the EU around the free movement rights of the poor. This leads her to criticise the much-debated Dano judgment of the CJEU from a new angle. Concluding that there is, indeed, the potential of transnational solidarity in the EU, even in the alleged absence of a European 'demos', she nevertheless explores limits of transnational financial solidarity, concluding that EU-level 'social engagement' is required to overcome the economic hurdles against integration of poor movers.

This line of argument leads to the next theme, EU social and labour policy, which is discussed in two articles. Konstantinos Alexandris Polomarkakis discusses the question of whether the removal of the UK as a veto player in social policy must be viewed as the silver lining of the Brexit cloud. Applying Tsebelis' analytical framework, he explores the UK's veto player role in detail, distinguishing ideological, party policy-related and Eurosceptic reasons for using a veto. Unsurprisingly, he comes to the conclusion that there may well be other Member States stepping into the void left by the British veto. Specifying his examination in relation to the diverse elements pursued under the Social Pillar implementation, he comes to a sobering conclusion. On the positive side, he does not find the same level of ideologically supported social policy veto in other Member States. However, states as different as Hungary, France and Germany are viewed as having good reasons to veto some social policy measures on the basis of party policy or Euroscepticism. Nevertheless, the conclusion is cautiously optimistic in favour of a slow and steady realisation of the Social Pillar, as long as abrupt changes of national social policy are not required of Member States.

Lukasz Pisarczyk takes up the challenge of discussing the future of EU labour and employment law from the perspective of Poland as an Eastern EU country. His question is similar to that asked by Polomarkakis: will social policy accelerate post-Brexit? His prediction is that the Eastern Member States may well step into the alleged void left by the UK as a veto player. In his view, this is due to the political perception of comparative (economic) advantage in these countries: often, the lower costs of labour are still perceived as decisive for remaining competitive. This, in turn, can lead to a reluctance to embrace EU social standards which require change at national level. However, he also notes that, as a result of free movement rights for Polish workers, the government has felt compelled to promote the return of those highly skilled workers who were the first to find better pastures in other EU countries. Among other strategies, the improvement of central employment conditions, such as the level of the minimum wage at national level, has been used to achieve that goal. Brexit may be perceived as a blessing in disguise in this situation as Polish workers in the UK may no longer feel welcome there and consider returning to Poland, while also weighing other options.

Roderic O'Gorman discusses the challenges of environmental protection through EU law and policy post-Brexit. As pollution and other environmental problems do not tend to stop at geographical borders, this is an area where the EU will be challenged to find a new relationship with the UK which prevents undercutting of standards and transnational import of environmental problems. Preferably, that regime would be as efficient as EU membership itself - but this option seems excluded. O'Gorman carefully 
develops the relevance of oft-rehearsed relationship models such as 'Swiss', 'Norwegian', Customs Union-only, and existing Association Agreements with neighbouring and other non-EU countries. After duly highlighting the complex legal problems, he suggests that an Association Agreement modelled upon the deep and comprehensive free trade agreements with neighbourhood countries offers the best perspective of respecting the UK's 'red lines' while not requiring the EU Member States to endure unregulated pollution through water, air and land. The conclusion is bleak in that we must recognise that no alternative to EU membership allows the same level of protection as EU membership itself.

The last two articles in the issue take up the specific issue arising at the fringes of the EU in the wake of Brexit. Robert Grzeszczak and Stephen Terrett explore the EU's role in policing the rule of law, reflecting on the current Article 7(1) TEU procedure pending against Poland. Maintaining functioning rule of law institutions in Member States may not appear immediately related to Brexit. However, as the Brexit vote has been viewed as one expression of right-wing populism's successes, the connection is not at all farfetched. The dismantling of judicial protection, and thus the precondition of the protection of rights, seems eerily reminiscent of one of the UK government's red lines relating to judicial protection. Grzeszczak and Terrett argue that the current legal framework for protecting the rule of law in existing Member States is insufficient due to structural inability of the EU institutions to engage effectively with the threat to limit membership rights. They illustrate their claim through a detailed account of how the Polish government has 'debilitated' the Polish Constitutional Court, concluding slightly depressingly that the only hope is that, while the EU 'waits the problem out', Polish civil society manages to challenge the government effectively.

Dagmar Schiek takes up a problem at the Western fringe of the EU, where Brexit is discussed as a 'border problem' on the island of Ireland, with additional challenges to the protection of human rights and equality rights. She challenges this perspective, identifying instead that the UK's withdrawal from the EU will hinder the hybridity of identities and territories on the island of Ireland. Further, the focus on avoiding physical infrastructure at the border overlooks the preconditions for socio-economic improvement in the lives of people in Northern Ireland, which depend on functioning legal frames for economic and civic cooperation. Those rely on maintaining the direct effects of EU economic freedoms and citizenship rights. Identifying that the Protocol on Ireland/Northern Ireland does not maintain all the economic freedoms, and relegates the citizenship rights to the Common Travel Area, she concludes that the EU Commission, in focusing on the physical infrastructure on the border and the formula of 'no diminution of rights', has offered to give up the indivisibility of the Internal Market for Northern Ireland alone. This has not only reinforced the demand of the UK to be allowed membership in the Internal Market without free movement of persons, but also does not satisfy the needs of Northern Ireland.

\section{Conclusion}

In debating the demands of Brexit for the EU, a common thread of the special issue has emerged. Maintaining the EU's social legitimacy requires taking citizenship rights as seriously as the realisation of the Pillar of Social Rights. EU citizenship rights so far encompass free movement of workers underpinned by equal treatment rights - a concept that today is challenged even by academics who have based their careers on defending it prior to Brexit. Areas as different as environmental protection, rule of law and the situation on the island of Ireland further underline the importance of maintaining judicial 
enforceability of EU rights after Brexit. From socio-legal perspectives, all this sounds like squaring a number of circles. On a positive note, this offers extensive opportunities for socio-legal research, not only up to the UK's withdrawal from the EU, but also beyond this point in relation to redefining citizenship rights, as well as social dimensions of economic freedoms, the safeguarding of efficient environmental protection and social and employment rights in the post-Brexit EU. 